\title{
Analysis of the Production Chain of Bean Culture in Brazil
}

\author{
Diandra Ganascini ${ }^{1}$, Jessica Cristina Urbanski Laureth ${ }^{1}$, Isaque Souza Mendes ${ }^{1}$, Luciene Kazue Tokura ${ }^{2}$, \\ Eduardo Lange Sutil ${ }^{2}$, Bruna de Villa ${ }^{2}$, Alessandra Mayumi Tokura Alovisi ${ }^{3}$, Ivã Luis Caon ${ }^{4}$, Erivelto Mercante ${ }^{5}$ \\ \& Silvia Renata Machado Coelho ${ }^{5}$ \\ ${ }^{1}$ Graduate Program, Doctor's in Agricultural Engineering, Western Paraná State University, Cascavel, Paraná, \\ Brazil \\ ${ }^{2}$ Graduate Program, Master's in Engineering of Energy in Agriculture, Western Paraná State University, \\ Cascavel, Paraná, Brazil \\ ${ }^{3}$ Post-graduation Program in Agronomy, Federal University of Grande Dourados, Dourados, Mato Grosso do \\ Sul, Brazil \\ ${ }^{4}$ Graduating in Agricultural Engineering, Western Paraná State University, Cascavel, Paraná, Brazil \\ ${ }^{5}$ Post-graduation Program in Agricultural Engineering, Western Paraná State University, Cascavel, Paraná, \\ Brazil \\ Correspondence: Diandra Ganascini, Graduate Program, Master's in Agricultural Engineering, State University \\ of West Paraná, Rua Universitária, 2069-Jardim Universitário, CEP: 85819-110, Cascavel, Paraná, Brazil. Tel: \\ 55-(45)-3220-7366. E-mail: diandraganascini@hotmail.com
}

Received: February 27, $2019 \quad$ Accepted: March 30, $2019 \quad$ Online Published: May 31, 2019

doi:10.5539/jas.v11n7p256 URL: https://doi.org/10.5539/jas.v11n7p256

The research is financed by Capes, CNPq, Fundep, Fundação Araucária and Fundação Parque tecnológico da Itaipu-PR.

\begin{abstract}
This bibliographical review brings information about the productive chain of beans, an essential product in the Brazilian diet, but present in several countries of the world. Beans are a source of protein, fiber, minerals and vitamins, allowing for healthy eating for easy access. Being, Brazil is the third largest producer of beans in the world, losing only to Myanmar and India, also the main consumer of beans in the world, having to import part of the beans consumed in Argentina. Due to iss, the bean culture is a promising crop, since the supply does not meet the domestic demand, being necessary the application of technologies that improve the yield and facilitate the cultivation. One of the obstacles of the crop is the susceptibility of the deterioration of the grains to store them, because, these grains stored, the commercial value tends to fall due to loss of quality. The objective of the work was to raise information on the productive chain of the beans. Periodicals, books, and information literatures were explored. Therefore, in view of the above, it was observed that in Brazil, the crop still needs to stimulate cultivation to supply domestic demand, improve storage conditions, invest in genetic improvement to maintain grain quality, and the study is necessary of new alternatives of destination for the residues generated by the processing and beneficiation of grains.
\end{abstract}

Keywords: Phaseolus vulgaris, yield, yield, storage

\section{Introduction}

Bean is a domesticated seed 7000 years old, grown in ancient Greece and not Roman Empire (Vieira, 2015). Currently, world production originates in six countries, accounting for $61 \%$ of production: Myanmar, India, Brazil, China Mexico and the United States (CONAB, 2017; Statfao, 2017). It is the third largest legume in the world preceded by soybean (Glycine $\max (\mathrm{L}$.) Merr.) and peanut (Arachis hypogea L.). It is a source of protein, dietary fiber, iron, complex carbohydrates, minerals and vitamins for millions of people in developed and developing countries (Mesquita et al., 2007; Lin et al., 2008).

For Brazilians, beans are important food, and represent a mandatory component of the population's diet. It is a very widespread crop throughout the national territory, being known as subsistence for small producers, however, 
has been gaining ground in recent years by producers of other social classes using new agricultural technologies (Yokoyama et al., 2001).

Bean is a legume for human consumption, therefore its acceptability is established by the quality of the grains, mainly by the color, which is associated to the cooking time of the grains (Shoeninger et al., 2012). In this sense, harvesting is one of the most important stages in the production chain (Souza et al., 2010), as the possibility of grain deterioration increases as harvest delay occurs after physiological maturation (Silva et al., 2009).

Grain storage is a process that deserves attention in the production chain, since storage time together with packaging and environmental conditions are the main causes of grain deterioration, especially in transparent grains whose damages are more apparent. Inappropriate conditions such as high temperature and humidity can cause the hard-to-cook effect, decreasing the commercial value of grains and acceptability by consumers. These grain yield processes generate waste, and these do not have adequate disposal, the review seeks to bring alternatives to their destination.

In view of this scenario, the present review aims to explain the current situation of the culture, raising information about the landscape that the culture is national and international, health benefits, harvesting, storage/processing, and explore alternatives for the destination of bean processing residues.

\section{Material and Methods}

For the present literature review, scientific articles, books, reports, dissertations, constitution and various materials dealing with aspects related to the bean production chain. Taking into account the scenario in which the crop is in the national and international scope regarding the export production and importation, health benefits linked to the consumption of this legume, harvesting to clarify the problems faced and how they are solved, storage/processing aiming the least loss of quality, as well as alternatives to the destination of bean processing residues that does not yet have its due destination.

\section{International and National Bean Culture Panorama}

Most of the world's production comes from only six countries: Myanmar, India, Brazil, China, Mexico and the United States, responsible for $61 \%$ of world production. Myanmar took the lead as a leader in world bean production in 2012, passing in front of Brazil and India (CONAB, 2017b, FAOSTAT, 2017). With regard to Mercosul countries, Brazil stands out as the largest producer, with 3 million tons per year, with a $90 \%$ share, both in production and consumption. Argentina is the second largest producer of Mercosul, with 350 thousand tons, with an exportable balance of 180 thousand tons. The main classes of beans produced are, common black and common white. Around $90 \%$ of the production of white beans is destined for the European Union, with Spain being the largest consumer, followed by Portugal, Italy and France. Black common beans are destined for export in their totality, with Brazil and Venezuela being the main importers of this class (CONAB, 2017b).

According to IBGE (2017), Brazil presented an area of approximately 78 million hectares of beans in 2016, and by 2017 the area reached approximately 3.1 million hectares of cultivated area. The area referring to the first harvest was approximately 1.7 million, the second of 1.1 million and the third of 200 thousand hectares of area sown. The average yield of the bean crop reached $2500 \mathrm{~kg} \mathrm{ha}^{-1}$ in the years 2016/2017 for the third harvest, while in the first and second crops, $900 \mathrm{~kg} \mathrm{ha}^{-1}$ and $1000 \mathrm{~kg} \mathrm{ha}^{-1}$, respectively. Compared to the values of 2015/2016, the first and second harvests obtained an increase of $100 \mathrm{~kg} \mathrm{ha}^{-1}$ in the year 2017.

The geographic distribution of the main bean producers in the country is relatively in several states, although the main ones are: Paraná, Minas Gerais, Mato Grosso, Goiás, Bahia and São Paulo, which currently produce 76.8\% of the national production. Other states like Santa Catarina and Maranhão produce $23.2 \%$ of the national production. For the 2016/17 crop year, the national production was 3327 thousand tons, with $76.8 \%$ concentrated in six Brazilian states. In the state of Paraná, production was 790 thousand tons, responsible for $23.8 \%$ of production, Minas Gerais with 536 thousand tons in $16.1 \%$, of production, Mato Grosso with 382 thousand tons in $11.5 \%$ of production, followed of Goiás with 292 thousand tons, Bahia with 288 thousand tons and São Paulo with 266 thousand tons (MAPA, 2017).

The state of Paraná is the main producer of beans. About 16 municipalities stand out in the national production: Prudentópolis, Irati, Tibagi, Vitorino, Castro, Ivaí, Palmeira, Reserva, Lapa, Pato Branco, Bom Sucesso do Sul, Cruz Machado, São João do Triunfo, Ipiranga, Campo Largo and Renascença. These municipalities, in 2016, represented $9 \%$ of the national production, with approximately 267 thousand tons (SEAB, 2016).

The consumers of beans have a very diversified food habit, as the preference for types, varieties and classes. The common bean cores have a higher consumption record in the central states, in part of Paraná and Santa Catarina, while the Caupi beans are consumed only in the northeast region of the country. Black bean, consumption is 
concentrated in Rio Grande do Sul and Rio de Janeiro, with small portions in the state of Paraná and Santa Catarina (CONAB, 2017a).

The cost of beans production has been increasing gradually from 2010 to 2016 by at least $56.4 \%$. The use of fertilizers stands out with approximately $18 \%$ representativeness in the average total cost of bean production, with a cost increase of $88.9 \%$, on average, in the last 5 years. The agrotoxic is the second largest participant responsible for about $15 \%$ of the costs, had a price increase of approximately $58 \%$. Then, the operations with machines with an average participation of around $14 \%$, followed by seeds with a $10 \%$ participation in costs with an increase of expenses of $11 \%$ (CONAB, 2016).

Although the bean culture has its importance in agriculture, there are large variations in the cultivated areas independent of the state of the country. This is due to the price fluctuations of the commercialized beans, causing the producer to choose to grow a more profitable crop in the face of the low commercial value in that crop (Yokoyama et al., 2001).

According to MAPA (2017), the annual expected growth rate of production is -0.5 to $1.6 \%$ over the next 10 years. Already the annual growth rate for bean consumption is projected at $-0.2 \%$ for the next decade. Knowing that the annual consumption has been about 3.0 million tons, needing to import 150 and 300 thousand tons per year, if the projections are confirmed there will be a need to import beans in the coming years.

Beans are a promising crop since the domestic production of the country is insufficient. Although Brazil is classified as the third largest producer of beans in the world, it depends on imports to supply domestic demand. Most of these imports come from Argentina, China and Bolivia, and almost all are from common black beans. The ideal would be to supply domestic consumption with increased production, which would consequently encourage employment generation and income growth (CONAB, 2017a).

\subsection{Benefits of Bean for Health}

Healthy food is considered an alternative for the prevention of chronic non-communicable diseases. The increase in fruit consumption vegetables and the stimulation of increased consumption of rice and beans are examples of adaptations in diets that are within reach of society as a whole. Healthy eating habits have great impact on the most important factors related to various diseases. Beans have high nutritive value, such as folic acid and iron, as well as fiber content (Sichieri et al., 2000; Luján et al., 2008), and easy access to the general population.

Beans are an interesting nutritional composition because their consumption is linked to a decrease in blood glucose and blood pressure levels, contributing to a reduction in the number of chronic-degenerative diseases, cardiovascular diseases and diabetes (Schoeninger, 2012). Luján et al. (2008) state that bean-based diets promote reduced levels of glucose, cholesterol and plasma triglycerides in relation to casein.

Carioca beans and white rice are the foods most consumed by the elderly in Brazil. This shows that the elderly population has preserved the food habit, being seen in a positive way in relation to the younger age group. In addition to be a typical dish from Brazil, there are studies that show that beans have beneficial properties against cancer (Freitas et al., 2011; Marchioni et al., 2007; Levy-Costa et al., 2005). The combination of beans and rice becomes the perfect blend when taken into consideration that, the beans are low in sulfur amino acids, and rich in lysine; and rice is low in lysine and relatively rich in sulfur amino acids. Beans when combined with rice form a more nutritious protein mixture (Mesquita et al., 2007).

Beans, despite having great health benefits, are losing their place to fast foods, due to the realization of women's space in the labor market. The time demanded at the time of preparation is inconvenient in the family routine, this makes the feeding of some age groups less healthy (Schoeninger, 2012). The Brazilian Ministry of Health (Brasil, 2006) reported that in 1974, the share of rice and beans in relation to the total energy consumption of the diet corresponded to $42.1 \%$, whereas in 2003 there was a decrease in consumption, and decreased to $38.7 \%$.

Ingestion of rice and beans in Brazil is very common because it is a typical Brazilian food. While the former is rich in starch (carbohydrate), it also provides iron (Fe), vitamin B complex and other minerals; the second is rich in proteins, fibers, $\mathrm{Fe}$ and zinc $(\mathrm{Zn})$, potassium $(\mathrm{K})$ and other minerals. Beans are an iron-rich food, there are reports that humans can absorb on average $10 \%$ of Fe contained in food, however, when accompanied by a food rich in vitamin $\mathrm{C}$, this absorption rises to $40 \%$, so that usually the presence of the orange as an accompaniment to the feijoada (Vieira, 2015).

\subsection{Bean Culture}

The genus Phaseolus belongs to the family Fabaceae, subfamily Papilionoideae and genus Phaseolus, containing approximately 55 species, being most cultivated: P. vulgaris L., P. lunatus L., P. coccineus L., P. acutifolius A. 
Gray var. latifolius Freeman and P. polyanthus Greenman (Mariot, 1989; Santos \& Gavinales, 2006). Phaseolus vulgaris L., commonly known as common bean or common bean, is the oldest in all continents (Santos \& Gavinales, 2006; Vieira, 2015).

Beans are the third most important legume in the world, losing only to soybeans (Glycine max (L.) Merr.) and peanuts (Arachis hypogea L.). Bean (Phaseolus vulgarius) is a source of protein, dietary fiber, iron, complex carbohydrates, minerals and vitamins to millions of people in developing and developed countries (Mesquita et al., 2007; Lin et al., 2008).

In Brazil the main cultivated species are: Phaseolus vulgaris L., existing in all national territory; the Vigna unguiculata, known as string bean, cowpea, planted in the Northeast region and the Amazon, and the Cajanus cajan, common in the Northeast region, in the tree variety, where it is called pigeon pea and Andu, cultivated as a recuperating plant, for having root pivotal and aggressive (Vieira, 2015).

Bean cultivation in Brazil occurs in three harvests in the same year: the harvest of water, drought and winter. Being that the first crop concentrated in the Southeast and South regions, with planting from August to February; the second crop with predominance in the Center-West and South regions, with the planting calendar from January to June; and the third harvest with emphasis on production in the Midwest, Southeast and Northeast, with planting from March to June (CONAB, 2016).

The crop cycle varies between 70 and 100 days, with two phases being vegetative (V) and reproductive (R), presented in Table 1 and Figure 1 (Quintela, 2001). The bean culture has been gaining ground due to its versatility as to the cycle being fast, to be able to be cultivated in three harvests, besides being a crop adaptable to several regions of the country.

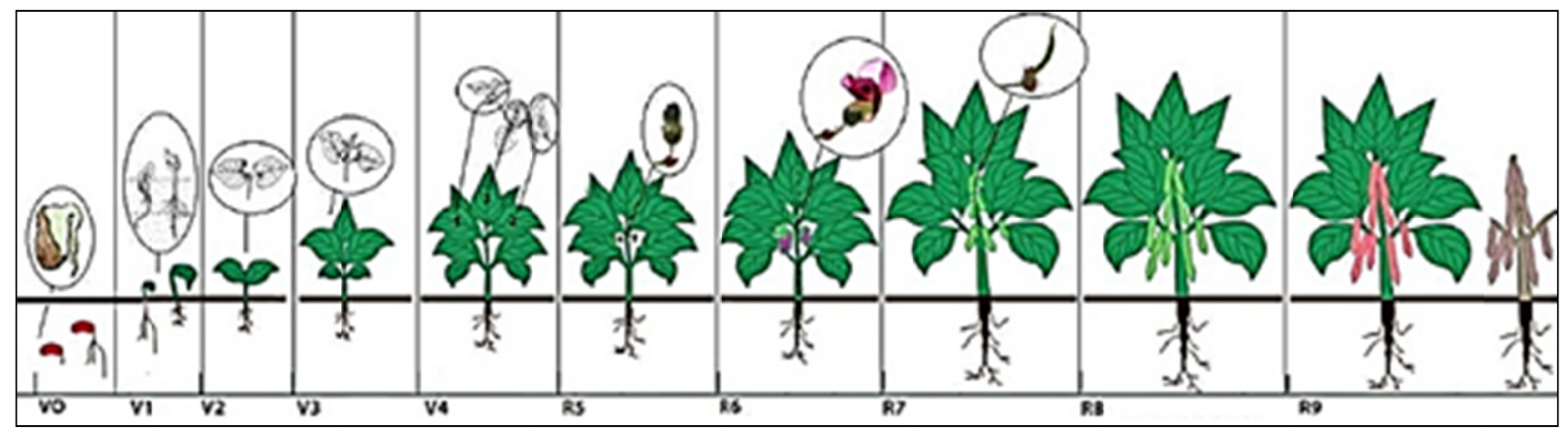

Figure 1. Representation of stages/stages of development of common bean

Source: Adapted from Quintela (2001).

The cultivation of winter beans along with the correct use of inputs and irrigation has enabled improvements in productivity. However, adjustments in management techniques are necessary, among them nitrogen fertilization in cover deserves special attention, since it allows for greater productivity and making bean cultivation more profitable (Binotti et al., 2010). Barbosa et al. (2012), and Meira et al. (2005) verified that the application of nitrogen $(\mathrm{N})$, independent of the vegetative stage of the plant, promotes an increase in seed productivity without altering its physiological potential.

Among the nutritional deficiencies that occur in bean culture, $\mathrm{N}$ is the most frequent. This is because $\mathrm{N}$ is the nutrient most absorbed by plants (Silva et al., 2000). Therefore, the availability of this nutrient is necessary, with correct dose and time, providing good nutrition at the moment when it is possible to increase the number of pods, that is, until the beginning of flowering (Carvalho et al., 2001). 
Table 1. Development stages/stages of common bean plant

\begin{tabular}{ll}
\hline Stadium & About us \\
\hline V0 & Germination: water absorption by seed; emergence of the radicle and its transformation into a primary root. \\
V1 & Emergence: Cotyledons appear at ground level and begin to separate. Epicotyl begins its development. \\
V2 & Primary leaves: primary leaves completely open. \\
V3 & First trifoliate leaf: opening of the first trifoliate leaf and the appearance of the second trifoliate leaf. \\
V4 & Third trifoliate leaf: opening of the third trifoliate leaf, the buds and lower nodes produce branches. \\
\hline R5 & Prefloration: the first floral bud and the first cluster appears. \\
R6 & Flowering: the first flower opens \\
R7 & Formation of pods: the first pod appears. \\
R8 & Filling the pods: the filling of the first pod (seed growth) begins. At the end of this stage, the seeds lose their green color and \\
& begin to show the characteristics of the cultivar. Defoliation begins. \\
R9 & Physiological maturation: The pods lose pigmentation and begin to dry. The seeds acquire the typical color of the cultivar. \\
\hline Note. $*$ Each stage begins when $50 \%$ of plants are defined as a description of the stage. \\
Source: Quintela (2001).
\end{tabular}

The quality of the seed is essential to obtain a sowing with a homogeneous plant stand to obtain high yields (Mambrin et al., 2015). The utilization rate of seed with quality certification is low, since most of the producers choose to use seeds from one year to another, a product saved from the previous harvest. Most producers do not have the habit of acquiring seeds every year, this is justified by the high cost of acquiring commercial seeds and lack of awareness, that sowing a seed of good sanitary and physiological quality, sowing is more homogeneous and consequently more assured (Yokoyama et al., 2001).

Only from 2016 will the producers' interest in certified seeds increase. If on the one hand the demand increased, on the other the supply in the market decreased, consequently, the use of grains for the planting grows. Although interest has increased, still $85 \%$ of the producers keep part of the production of the grains for the next harvest, as if it were a seed. Producers thus lose productivity and quality of final product (CONAB, 2017b).

\subsection{Genetic Improvement of the Bean}

Genetic improvement has sought plants with high production potential, resistance to diseases, plants with architecture that facilitates cultural treatment and mechanized harvesting. There is a preference for erect plants that have been one of the main requirements of both rural entrepreneurs and family farmers (Silva et al., 2009).

In addition, the genetic improvement cannot leave aside the production of quality seeds with characteristics desirable by the consumer, as to the shape, color and brightness, good culinary and nutritional characteristics such as ease of cooking, good palatability, soft tegument texture, the ability to produce light and dense broth after cooking, higher protein and mineral content (Mesquita et al., 2007). In addition to good physiological and agronomic characteristics, a limiting factor for breeding is consumer demand, which delimits the priorities of the breeding program. Among the visual characteristics of grains, color has been highlighted by the highest requirements (Silva, 2012).

One of the influence factors in the production is the climatic conditions, and the availability of water in the soil is essential for bean production, since it is a limiting factor, since the plants are sensitive to water stress during the critical phases: germination, flowering and grain filling (Soratto et al., 2003).

Bean is considered a crop with little tolerance to water stresses, since about $60 \%$ of world production is subject to this factor, with drought being the second largest reducer of productivity, which is overcome only by the occurrence of diseases (Aguiar et al., 2008).

The temperature of the air is one of the most important and determinant elements of its exploitation in several regions, since this culture is cultivated at temperatures between 10 and $35^{\circ} \mathrm{C}$. The temperature is a factor that affects not only the phytomass accumulation but also the duration of the phenological stages of development of the species, and to complete each subperiod of development the plant needs a certain thermal accumulation (Mariot, 1989). One of the main obstacles of the commercialization culture is the fact that the largest production is from the Rio group, being of high deterioration, the group is the national preference group, but of limited acceptance in other countries. Therefore, when there is a crop failure, the product becomes scarce, raising the cost, since there is no alternative for import, and when there is a production surplus, there is no way to transfer 
the surplus to the foreign market, this causes prices to fall, the merchandise deteriorates, darkens and loses quality inside the warehouses (CONAB, 2017b).

Bean cultivation, despite being much cultivated for subsistence in small farms and in family agriculture, is also cultivated by large landowners increasingly in need of technology and innovation, in this context mechanized harvesting is already a more than necessary operation (Mata, 2015).

To enable mechanization of the harvest, with low potential for grain losses, it is necessary the development of bean plants with size and erect, good height of pod insertion, uniformity of maturation and resistance to lodging and dehiscence of the pods under conditions (Silva et al., 2009).

\subsection{Mechanical Harvesting Linked to the Use of Desiccants}

Harvesting is an important step in the bean production chain, among others, it deserves to be highlighted, due to the difficulties and high costs involved, whether it is done manually, mechanized or by the combination of both (Souza et al., 2006, 2010).

The harvest that uses manual and mechanical processes or commonly known as semi-mechanized, consists in pulling the whole plants, when they reach their physiological maturation. At this stage the plants are devoid of leaves, and the seeds have low water content. After the starter, lees are formed that remain in the crop to complete the process of drying and natural homogenization and, finally, an operation in which a harvester, conventional or bean specific, collects the product and separates the seed from the rest of the plant (Souza et al., 2006).

When comparing the semi-mechanized harvest with that of an automated harvester, the second one can cause more losses and damages to the grains, as well as soil contamination and, consequently, the producers become resistant to the harvesters. As it is a culture of ununiform physiological maturation, besides the damages caused to the grains, the plant needs desiccation with herbicides to force the loss of moisture, burdening even more cost (Silva et al., 2009).

The possibility of deterioration of the grains increases as the harvest delay occurs, due to this the use of desiccants is an alternative to promote the drying and fall of the leaves, and promotes the rapid reduction of water in the grains making possible the harvesting in the ideal period, close to physiological maturation. If on the one hand the use of desiccants speeds the drying of the product, depending on the way in which it is applied, type and mode of action, on the other, the practice of desiccation can compromise the quality of the seeds, leave residues accumulated in the composition of the product (Lacerda et al., 2005; Kappes et al., 2009).In the present study, it is possible to compare the results of the present study.

According to Gaultier and Gulden (2016) in a survey conducted in Canada and the USA between $60 \%$ and $85 \%$ of the cultivated bean areas are dried out. This shows that desiccation in bean culture is increasingly being spread in the agricultural sector. The objective of this practice is to liberate the area in advance for the crop in succession and to eliminate possible late infestations of weeds, mainly to reduce the water content of the grains, enabling harvesting in the physiological maturation (Santos et al., 2005; Pinto et al., 2014).

When the bean seed is harvested with humidity above $18 \%$, there is a risk of losses at the time of harvest due to the high humidity of the grain, but if it is very dry (humidity around 14\%), the seed will be broken. The optimum would be to harvest at physiological maturation, requiring a rapid reduction of humidity at levels compatible with the operation, considering maintaining and preventing seed quality (Domingos et al., 1997).

\subsection{Storage and Processing}

The grain of beans stored in silos or bags presents as a porous mass, consisting of grains and intergranular spaces (air).The oxygen contained in the intergranular spaces is used in the respiratory process of the seeds, accompanied by the wear of the nutritive substances. The temperature and humidity of the air are factors that influence the deterioration of the grains, since they are directly connected to the respiratory process. Therefore, if the humidity of the grains is between 11 and $13 \%$ the respiratory process is low and the maintenance of product quality is prolonged, however, the higher the humidity, the faster the breathing process is accelerated and consequently the deterioration occurs (Bragantini, 2005).

Bean storage is a process that requires attention because the grain cells remain alive, therefore, their metabolic processes are active. During storage there are damages that can occur in grains, such as: cracking of the shell (integument), caused by a low humidity of the environment; occurrence of pests and fungi that contaminate the beans, rendering it unfit for human consumption; increase in cooking time/Hard to Cook effect (HTC), due to excessive hardening of the grain; decreased germination (Brackmann \& Neuwald, 2002; Brackman et al., 2002). 
In the present study, it was found that the color of the bark increased significantly. In addition, HTC changes the chemical compositions of the grains, decreasing $\mathrm{pH}$, solubility and modifying the electrophoretic profile of proteins (Ribeiro et al., 2005; Lima, 2013).

The storage time allied to the packaging conditions and storage environment are the main causes of grain deterioration. An alternative to bean storage, keeping the cooking time with the lowest quality losses is cold storage (Morais et al., 2010). The drawback of this type of storage is the high cost of equipment and the consumption of electric energy, thus making the practice impracticable on a commercial scale.

In grain storage, significant quality losses occur, especially in light-skinned beans, such as those of the Rio group. These losses mainly occur due to the darkening and hardening of the integument, increasing the cooking time and generating losses of nutritional quality of the beans. The color of the tegument is a limiting factor in the consumers' purchase of beans, since the color is associated with the storage and hardening time, thus, dark-colored grains suffer greater rejection (Silva, 2012; Lima, 2013).

Another factor that affects the cooking time of the beans is the drying temperature of the beans shortly after harvest. When exposed for a long time, drying in full sun, drastically reduces humidity and water reabsorption hardly occurs, consequently the cooking time is prolonged (Silva, 2007; Mota, 2016).

The water absorption capacity is related to bean quality, and grains that absorb more water tend to be easier to cook, a characteristic that is important at the moment of commercialization (Delfino et al., 2010). Ganascini et al (2014), when evaluating the cooking time of bean varieties observed that the higher the grain water absorption percentage, the shorter the cooking time, thus reducing costs with energy expenditure for the preparation of the legume.

The hardening of the bean grains has been related to the action of the polyphenols, through the polymerization in the tegument or by the lignification of the cotyledons, both influencing the water absorption capacity of the grains, the first hinders the penetration of water and the second limits the capacity of water absorption (Moura, 1998; Lima, 2013).

The darkening and hardening of the bean seed coat are related to enzymatic oxidation of peroxidase and polyphenol oxidase, which depend on the presence of oxygen to polymerize low molecular weight phenols into high molecular weight compounds which have a dark color (Lima, 2013). Among the most important polyphenols, tannins deserve special mention, since they have the ability to interact with proteins, reducing protein digestibility and contributing to the formation of dark grain color (M. R. Silva \& M. A. A. P. da Silva, 1999; Blair et al., 2006; Lima, 2013; Franco, 2015).

\subsection{Alternative for Crop Residues}

Residues from bean processing have been a concern of large companies, since broken grains and broken grains are basically discarded in storage and processing units. Research has been carried out in search of alternatives for the destination and mainly use of these wastes.

In both the rice and bean processing, the generation of by-products such as "quirera" and "bandinha" occurs, which commercially are worth less than whole grains. Rice cherry is a byproduct resulting from the breaking of the grains at the moment of polishing, the bean band comes from the grain that broke the integument and divided the cotyledons (Castro et al., 1999).

The main aspect to be considered are the ant nutritional factors present in the beans, making it necessary to use heat treatment before consumption, usually cooking. This heat treatment is used both domestically and industrially, increasing the digestibility by protein denaturation and gelatinization of the starch, in addition, inactive toxic substances. Another method used as heat treatment is extrusion, which promotes the gelatinization of the starch, resulting in great water absorption, allowing also the more extensive proteolysis and favoring the protein digestibility (Cardoso Filho, Ciacco, \& Sgarbieri, 1993, 1996).

Soares et al. (2011) emphasize that both beans and rice are important sources of carbohydrate and protein in the Brazilian people's diet, contributing about half of the energy and protein intake of the individuals. The authors also report that the major challenge of the industries is to develop convenience products, such as cereals and snacks of high nutritional value, to meet the needs of the population. With this in mind, the idea of developing extruded snack foods from rice and beans fragments (by-products) comes as an alternative, both to the use of residues and to alternatives to increase food. The extruded snacks were well accepted by the consumer, and the acceptance was higher when the content of rice flour was higher. The addition of bean paste flour made the snack more nutritious without raising the energy value. 
The development of new food products with the use of rice and beans flour, with added nutritional and functional value, is increasingly being encouraged. The substitution of wheat flour for rice flour becomes interesting, considering the fact that Brazil is self-sufficient in rice production and a large importer of wheat. Another advantage of rice flour compared to wheat is the absence of gluten, making it an alternative for celiac people, intolerant to gluten (Silveira et al., 1981; Bottini, 2008). However, the use of bean flour is advantageous because of the high fiber and protein content and low cost (Prolla, 2006).

The substitution of $50 \%$ of wheat flour for rice bran flour and bean broth in different proportions in the manufacture of cakes, meet the requirements of the market, presenting technological properties, acceptability and stability comparable to that of the standard formulation. The mixture of these flours provides a nutritional complement and represents an interesting and viable alternative in the production of cakes for substitution of wheat flour. Another alternative is the biscuits produced from the mixed flour of rice and beans, which have the potential to serve the growing Brazilian market of ready-to-eat products, especially to the gluten-intolerant public (Bassinelo et al., 2010, 2012).

Another alternative for the use of bean residues has been in the feeding of animals, by the greater availability of food and nutrients and reduction in the costs of their creation. The supply of agro industrial waste can optimize economic and environmental gains, reducing the cost of food and minimizing the deposition of waste in the environment. Comparing residues from bean processing and processing with other protein sources conventionally used in ruminant feed, such as soybean meal, sunflower cake and cottonseed meal, bean residue is an alternative with nutritional potential for animal feed (Castro et al., 2015).

By-products and residues resulting from the processing and/or processing of grains in general, are a promising alternative to the reduction of dairy herd costs. According to Magalhães et al. (2008), with regard to residues from bean processing and processing, the issue is somewhat more complicated due to the low digestibility of the bean in nature. For this reason, the inclusion of bean residue in whole concentrate and corn silage diets for dairy cows resulted in reduced milk production, although it did not compromise the efficiency of food use. Therefore, it is suggested that new studies be done to evaluate the adequate inclusion levels of bean residue for lactating dairy cows.

Soybean meal is the main source of vegetable protein in diets for fish, cattle and pigs. Because it is a commodity, its price is strongly influenced by world demand, making its export at some times more advantageous to the detriment of the domestic market. This generates great oscillations of price and is often disadvantageous the use of this legume in the diet of the animals. Therefore, the search for protein sources in substitution of soybean meal is a viable strategy for the reduction of costs with the formulation of animal diets. Studies with alternative sources of protein for tilapia production are abundant; however, there are few previous studies on the use of Phaseolus vulgaris. Studies showing the inclusion of up to $6.2 \%$ of bean by-product flour for up to 45 days did not affect the performance and body composition of juveniles of Nile tilapia, and it was possible to increase bean residues in the diet (Azevedo et al., 2017).

\section{Conclusion}

In the beans production chain, the responsibility for the final quality product comes from the farmer, with the product still in the field, drying, store up to the final trader.

$>$ Bean cultivation is $61 \%$ concentrated in only 6 countries. Consumption is not very expressive in developing countries; however, Brazil still needs to expand the culture to meet domestic demand and reduce the need for imports.

$>$ The beans are an interesting nutritional composition food with beneficial health properties, reducing blood glucose levels, blood pressure and also have advantageous properties against cancer.

$>$ The crop needs genetic improvement with cultivars less susceptible to color change, caused by the storage time of grains.

$>$ To improve the efficiency and quality of the product during the storage, with implantations of new technologies.

The need to apply desiccants to standardize the physiological maturation of the crop, which allows mechanized harvesting to ensure quality.

$>$ The correct and efficient destination for residues from grain processing still requires more elaborate studies since the alternatives mentioned in this review did not solve the question. 


\section{Acknowledgments}

The Unioeste for the support, structure and research opportunity. A Capes, CNPq, Fundep, Fundação Araucária and Fundação Parque tecnológico da Itaipu-PR for supporting the development of the research.

\section{References}

Aguiar, R. S., Moda-Cirino, V., Faria, R. T., \& Vida, L. H. I. (2008). Avaliação de linhagens promissoras de feijoeiro (Phaseolus vulgaris L.) tolerantes ao déficit hídrico. Semina: Ciências Agrárias, 29, 1-13. https://doi.org/10.5433/1679-0359.2008v29n1p1

Azevedo, K. S. P., Santos, M. C., Chung, S., \& Bicudo, A. J. A. (2017). Farinha do subproduto de feijão Phaseolus vulgaris em dietas para juvenis de tilápia do Nilo. Boletim de Indústria Animal, 74, 79-85. https://doi.org/10.17523/bia.v74n2p79

Barbosa, R. M., Costa, D. S. da, Homem, B. F. M., \& Sá, M. E. de. (2012). Nitrogênio na produção e qualidade de sementes de feijão. Pesquisa Agropecuária Tropical, 41, 470-474. https://doi.org/10.5216/pat. v41i3.12761

Bassinello, P. Z., Carvalho, R. N., de Almeida, R. P., Araújo, M. R., \& Cobucci, R. D. (2010). Desenvolvimento de mistura para bolo com farinhas de quirera de arroz e bandinha de feijão. Santo Antônio do Goiás: Embrapa Arroz e Feijão.

Bassinello, P. Z., Carvalho, R., Araújo, M., Almeida, R. P., \& Cobucci, R. D. (2012). Potencial de aproveitamento de farinhas de quirera de arroz e bandinha de feijão em biscoitos tipo cookie. Santo Antônio do Goiás: Embrapa Arroz e Feijão.

Binotti, F. F. S., Arf, O., Cardoso, E. D., De Sá, M. E., Buzetti, S., \& Nascimento, V. (2010). Fontes e doses de nitrogênio em cobertura no feijoeiro de inverno irrigado no sistema plantio direto. Bioscience Journal, 26, 770-778.

Blair, M. W., Iriarte, G., \& Beebe, S. (2006). QTL analysis of yield traits in an advanced backcross population derived from a cultived Andean $\times$ wild common bean (Phaseolus vulgares L.) cross. Theoretical and Applied Genetics, 112, 1149-1163. https://doi.org/10.1007/s00122-006-0217-2

Bottini, R. L. (2008). Arroz: História, variedades, receitas. São Paulo: Editora SENAC.

Brackman, A., \& Neuwald, A. D. (2002). Feijão para durar. Pelotas: Revista Cultivar. Retrieved from http://www.grupocultivar.com.br/artigos/feijao-para-durar

Brackmann, A., Neuwald, D. A., Ribeiro, N. D., \& Freitas, S. T. (2002). Conservação de três genótipos de feijão (Phaseolus vulgaris L.) do grupo carioca em armazenamento refrigerado e em atmosfera controlada. Ciência Rural, 32, 911-915. https://doi.org/10.1590/S0103-84782002000600001

Bragantini, C. (2005). Alguns aspectos do armazenamento de sementes e grãos de feijão. Santo Antônio de Goiás: Embrapa Arroz e Feijão.

Brasil. (2006). Guia Alimentar para a População Brasileira: Promovendo a alimentação saudável. Brasília: Ministério da Saúde. Retrieved from http://189.28.128.100/nutricao/docs/geral/guia_alimentar_conteudo. pdf.

Cardoso Filho, N., Ciacco, C. F., \& Sgarbieri, V. C. (1993). Efeito das variáveis do processo de extrusão nas características nutricionais das proteínas do feijão comum. Ciência e Tecnologia de Alimentos, 13, 142-150.

Cardoso Filho, N., Ciacco, C. F., \& Sgarbieri, V. C. (1996). Efeito de algumas variáveis do processo de extrusão nas características tecnológicas da farinha do feijão comum. Ciência e Tecnologia de Alimentos, 16, 158-164.

Carvalho, M. A. C., Arf, O., Sá, M. E., Buzetti, S., Santos, N. C. B., \& Bassan, D. A. (2001). Produtividade e qualidade de sementes de feijoeiro (Phaseolus vulgaris L.) sob influência de parcelamentos e fontes de nitrogênio. Revista Brasileira de Ciência do Solo, 25, 617-624. https://doi.org/10.1590/S010006832001000300010

Castro, E. M., Vieira, N. R. A., Rabelo, R. R., \& Silva, S. A. (1999). Qualidade de grãos em arroz. Santo Antônio de Goiás: Embrapa Arroz e Feijão.

Castro, W. J. R. (2015). Resíduo do beneficiamento de feijão em rações para ovinos (Dissertação (Mestrado em Ciência Animal), Universidade Federal de Mato Grosso, Cuiabá).

CONAB (Companhia Nacional de Abastecimento). (2016). Evolução dos custos de produção de feijão no brasil 
e sua rentabilidade: Safra 2010/11 a 2015/16. Brasília: Companhia Nacional de Abastecimento. Retrieved from http://www.CONAB.gov.br

CONAB (Companhia Nacional de Abastecimento). (2017a). Proposta de Preços Mínimos/Companhia Nacional de Abastecimento. Brasília: Companhia Nacional de Abastecimento. Retrieved from http://www.CONAB.gov.br

CONAB (Companhia Nacional de Abastecimento). (2017b). Perspectiva para a agropecuária. Brasília: Companhia Nacional de Abastecimento. Retrieved from http://www.CONAB.gov.br

Delfino, R. A., \& Canniatti-Brazaca, S. G. (2010). Interação de polifenóis e proteínas e o efeito na digestibilidade proteica de feijão comum (Phaseolus vulgaris L.) cultivar Pérola. Ciência e Tecnologia de Alimentos, 30, 308-312. https://doi.org/10.1590/S0101-20612010000200003

Domingos, M., Silva, A. A., \& Silva, R. F. (1997). Qualidade da semente de feijão afetada por dessecantes, em quatro estádios de aplicação. Revista Brasileira de Sementes, 19, 276-283. https://doi.org/10.17801/01013122/rbs.v19n2p275-282

FAOSTAT. (2017). Organização para a Alimentação e Agricultura dos Estados Unidos. Retrieved from http://www.fao.org/home/en

Franco, F. W. (2015). Armazenamento refrigerado, em atmosfera modificada e controlada na conservação das qualidades fisico-quimicas e sensoriais de cultivares de feijão carioca (62 f., Dissertação (Mestrado em ciências e tecnologia de alimentos), Universidade Federal de Santa Maria, Santa Maria).

Freitas, A. M. de P., Plilippi, S. T., \& Ribeiro, S. M. L. (2011). Listas de alimentos relacionadas ao consumo alimentar de um grupo de idosos: análises e perspectivas. Revista Brasileira de Epidemiologia, 14, 161-177. https://doi.org/10.1590/S1415-790X2011000100015

Ganascini, D., Wunsch, C. A., Schoeninger, V., Soncela, R. F., Bischoff, T. Z., Coelho, S. R. M., \& Gurgacz, F. (2014). Tempo de cozimento em três diferentes cariedades de feijão carioca. Acta Iguazu, 3, 79-86.

Gaultier, J., \& Gulden, R. (2016). The science and art of dry bean desiccation. Crops Soils. https://doi.org/ $10.2134 / \operatorname{cs} 2016-49-0403$

IBGE. (2017). LSPA-Tabelas de Novembro 2017. Brasília: Instituto brasileiro de geografia e estatística. Retrieved from https://sidra.ibge.gov.br/pesquisa/lspa/tabelas

Kappes, C., Carvalho, M. A. C., \& Yamashita, O. M. (2009). Potencial fisiológico de sementes de soja dessecadas com diquat e paraquat. Scientia Agraria, 10, 1-6. https://doi.org/10.5380/rsa.v10i1.12520

Lacerda, A. L. S, Lazarini, E., \& De Sá, M. E. (2005). Efeitos da dessecação de plantas de soja no potencial fisiológico e sanitário das sementes. Bragantia, 64, 447-457. https://doi.org/10.1590/S0006-87052005000 300015

Levy-Costa, R. B, Sichieri, R., Pontes, N. S., \& Monteiro, C. A. (2005). Disponibilidade domiciliar de alimentos no Brasil: Distribuição e evolução (1974-2003). Revista de Saúde Pública, 39, 530-40. https://doi.org/ 10.1590/S0034- 89102005000400003

Lima, R. A. Z. (2013). Armazenamento de feijão: uso da embalagem a vácuo na manutenção da qualidade (107f., Tese (Doutorado em Agroquímica), Universidade Federal de Lavras, Lavras).

Lin L.-Z., Harnly, J. M., Pastor-Corrales M. S., \& Luthria D. L. (2008). The polyphenolic profiles of common bean (Phaseolus vulgaris L.). Food Chemistry, 107, 399-410. https://doi.org/10.1016/j.foodchem.2007. 08.038

Luján, D. L. B., Leonel, A. J., Bassinello, P. Z., \& Costa, N. M. B. (2008). Variedades de feijão e seus efeitos na qualidade proteica, na glicemia e nos lipídios sanguíneos em ratos. Ciência e Tecnologia de Alimentos, 28, 142-149. https://doi.org/10.1590/S0101-20612008000500022

Magalhães, A. L. R., Zorzi, K., Queiroz, A. D., Mello, R., Detmann, E., \& Pereira, J. C. (2008). Resíduo proveniente do beneficiamento do feijão (Phaseolus vulgaris L.) em rações para vacas em lactação: consumo, digestibilidade, produção e composição do leite e eficiência de alimentação. Revista Brasileira de Zootecnia, 37, 529-537. https://doi.org/10.1590/S1516-35982008000300019

Mambrin, R. B., Ribeiro, N. D., Storck, L., \& Domingues, L. D. S. (2015). Seleção de linhagens de feijão (Phaseolus vulgaris L.) baseada em caracteres morfológicos, fenológicos e de produção. Revista de Agricultura, 90, 141-155. 
MAPA (Ministério da Agricultura, Pecuária e Abastecimento). (2017). Projeções do agronegócio: Brasil 2016/2017 a 2026/2027-Projeções de longo prazo. Brasília: Ministério da Agricultura, Pecuária e Abastecimento. Retrieved from http://www.agricultura.gov.br

Marchioni, D. M. L., Fisberg, R. M., Filho, J. F. G., Kowalsk, L. P., Carvalho, M. B., Abrahão, M., ... Wünsch-Filho, V. (2007). Fatores dietéticos e câncer oral: Estudo caso-controle na região metropolitana de São Paulo, Brasil. Cadernos de Saúde Pública, 23, 553-564. https://doi.org/10.1590/S0102-311X20 07000300014

Mariot, E. J. (1989). Ecofisiologia do feijoeiro. Londrina: IAPAR.

Mata, D. C. (2015). Dessecação pré-colheita de cultivares de feijoeiro-comum com diferentes princípios ativos (78f., Dissertação (Mestrado em Fitotecnia), Universidade Federal de Lavras, Lavras).

Meira, F. A., Sá, M. E., Buzetti, S., \& Arf, O. (2005). Doses e época de aplicação de nitrogênio no feijoeiro irrigado cultivado em plantio direto. Pesquisa agropecuária Brasileira, 40, 383-388. https://doi.org/ 10.1590/S0100-204X2005000400010

Mesquita, F. R., Corrêa, A. D., Abreu, C. D., Lima, R. A. Z., \& Abreu, A. D. (2007). Linhagens de feijão (Phaseolus vulgaris L.): Composição química e digestibilidade proteica. Ciência e Agrotecnologia, 3, 1114-1121. https://doi.org/10.1590/S1413-70542007000400026

Morais, P. P. P., Valentini, G., Guidolin, A. F., Baldissera, J. N. C. B., \& Coimbra, J. L. M. (2010). Influência do período e das condições de armazenamento de feijão no tempo de cocção. Revista Ciência Agronômica, 41, 593-598. https://doi.org/10.1590/S1806-66902010000400011

Mota, D. H. (2016). Propriedades físicas durante a secagem e qualidade tecnológica em cultivares de feijão carioca em diferentes condições de armazenamento (163 f., Dissertação (Mestrado em Agronomia), Faculdade de Agronomia e Medicina Veterinária, Universidade de Brasília).

Moura, A. C. C. (1998). Análises físico-químicas e enzimáticas antes e após armazenamento em grãos de feijão (Phaseolus vulgaris L.) submetidos a diferentes tempos e tipos de secagem (70 f., Dissertação (Mestrado em Ciência dos Alimentos), Universidade Federal de Lavras, Lavras).

Pinto, M. A. B., Basso, C. J., Kulczynski, S. M., \& Bellé, C. (2014). Productivity and physiological quality of seeds with burn down herbicides at the pre harvest of bean crops. Journal of Seed Science, 36, $384-391$. https://doi.org/10.1590/2317-1545v36n4997

Prolla, I. R. D. (2006). Características físico-químicas de cultivares de feijão (Phaseolus vulgaris L.), e efeitos biológicos da fração fibra solúvel (113f., Dissertação (Mestrado em Bioquímica toxicológica), Universidade Federal de Santa Maria, Santa Maria).

Quintela, E. D. (2001). Manejo integrado de pragas do feijoeiro. Santo Antônio de Goiás: Embrapa-CNPAF.

Ribeiro, H. J. S. S., Prudencio-Ferreira, S. H., \& Miyagui, D. T. (2005). Propriedades físicas e químicas de feijão comum preto, cultivar Iapar 44, após envelhecimento acelerado. Ciência e Tecnologia em Alimentos, 25, 165-169. https://doi.org/10.1590/S0101-20612005000100027

Santos, J. B., \& Gavilanes, M. L. (2006). In C. Vieira, T. J. Paula Júnior, \& A. Borém (Eds.), Botânica. Viçosa: Universidade Federal de Viçosa.

Santos, J. B., Ferreira, E. A., Ferreira, E. M., Silva, A. A., \& Ferreira, L. R. (2005). Efeitos da dessecação de plantas de feijão sobre a qualidade de sementes armazenadas. Planta Daninha, 23, 645-651. https://doi.org/ $10.1590 / \mathrm{S} 0100-83582005000400012$

Schoeninger, V. (2012). Otimização de parâmetros de pré-processamento para obtenção de feijão seco com reduzido tempo de cozimento (5f., Dissertação (Mestrado), Programa de Pós-Graduação em Engenharia Agrícola, Universidade Estadual do Oeste do Paraná, Cascavel).

SEAB. (2016). Feijão-Análise da conjuntura agropecuária. Curitiba: DERAL (Departamento de Economia Rural).

Sichieri, R., Coutinho, D. C., Monteiro, J. B., \& Coutinho, W. F. (2000). Recomendações de alimentação e nutrição saudável para a população brasileira. Arquivos Brasileiros de Endocrinologia e Metabologia, 44, 227-232. https://doi.org/10.1590/S0004-27302000000300007

Silva, C. S. (2012). Potencial genético de populações segregantes de feijoeiro-comum para escurecimento e cocção dos grãos (104f., Dissertação (Mestrado em Melhoramento de Plantas), Universidade Federal de 
Goiás, Goiânia).

Silva, G. S. (2007). Controle genético do escurecimento precoce de grãos de feijão tipo carioca (65f., Dissertação (Mestrado em Genética e melhoramento de plantas), Universidade Federal de Lavras, Lavras).

Silva, J. G., Aidar, H., \& Kluthcouski, J. (2009). Colheita de feijão com colhedora automotriz axial. Pesquisa Agropecuária Tropical, 39, 371-379.

Silva, M. R., \& Silva, M. A. A. P. da. (1999). Aspectos nutricionais de fitatos e taninos. Revista de Nutrição, 12, 21-32. https://doi.org/10.1590/S1415-52731999000100002

Silva, T. R. B., Soratto, R. P., Chidi, S. N., Arf, O., Sá, M. E., \& Buzetti, S. (2000). Doses e épocas de aplicação de nitrogênio em cobertura na cultura do feijoeiro de inverno. Cultura agronômica, 9, 1-17.

Silveira, E., Travaglini, D., Vitti, P., Campos, S., Aguirre, J., Figueiredo, I., \& Shirose, I. (1981). Farinha composta de resíduo do extrato de soja e de arroz em mistura com trigo para uso em panificação. Boletim do Instituto de Tecnologia de Alimentos, 18, 543-561.

Soares Júnior, M. S., Santos, T. P. B., Pereira, G. F., Minafra, C. S., Caliari, M., \& Silva, F. A. D. (2011). Desenvolvimento de salgadinhos extrusados a partir de fragmentos de arroz e de feijão. Semina: Ciências Agrárias, 32, 191-200. https://doi.org/10.5433/1679-0359.2011v32n1p191

Soratto, R. P., Orivaldo, A. R. F., Rodrigues, R. A. F., Buzetti, S., \& Silva, T. R. B. (2003). Resposta do feijoeiro ao preparo do solo, manejo de água e parcelamento do nitrogênio. Acta Scientiarum Agronomy, 25, 89-96. https://doi.org/10.4025/actasciagron.v25i1.2453

Souza, C. M. A., Bottega, E. L., Velloso, F. V., Rafull, L. Z. L., \& Queiroz, D. M. (2010). Espacialização de perdas e da qualidade do feijão em colheita semimecanizada. Acta Scientiarum Agronomy, 32, 201-208.

Souza, C. M. A., Queiroz, D. M., \& Pinto, F. A. C. (2006). Colheita de Feijão. In C. Vieira, T. J. Paula Júnior, \& A. Feijão (Eds.), Viçosa: Universidade Federal de Visçosa.

Vieira, J. D. (2015). O outro lado do feijoeiro-O lado humano da cadeia produtiva desta leguminosa (1st ed.). Timburi: Cia do ebook.

Yokoyama, L. P., Carneiro, G. E. S., \& Villar, P. M. D. (2001). Aspectos conjunturais, produção e uso de sementes das cultivares de feijão recomendadas pela Embrapa no estado do Paraná. Santo Antônio do Goiás: Embrapa Arroz e Feijão.

\section{Copyrights}

Copyright for this article is retained by the author(s), with first publication rights granted to the journal.

This is an open-access article distributed under the terms and conditions of the Creative Commons Attribution license (http://creativecommons.org/licenses/by/4.0/). 